\title{
Intensive residential densification: Impact on the urban morphology of Santiago de Chile
}

\author{
Magdalena Vicuña \\ Instituto de Estudios Urbanos y Territoriales, Pontificia Universidad Católica de Chile. \\ Providencia, Santiago, Chile \\ E-mail:mvicunad@uc.cl
}

\begin{abstract}
Areas of growing centrality in Santiago de Chile are currently under processes of residential densification, which vary in degrees of intensity and forms of impact in the urban environment. As a result of a weak conduction of residential densification, the structural-radical transformation of the urban fabric has resulted in the degradation of urban space. However, if well designed and planned, residential densification is a form of urban growth that can optimize infrastructure and allow the development of more complex and inclusive cities. This work aims to understand to what extent urban morphology shapes these urban transformation processes in 15 selected areas; the work also proposes typologies of residential densification based on the intensity of the process and the state of transformation of the urban fabric. Density (dwelling units/hectare) is understood as a systemic relation with parameters that determine urban compactness and configure public space such as lot subdivision composition, setbacks, building footprint and height, floor area ratio and mixed use index, among others. The study concludes that the impact of intensive densification on urban space can have three main effects: (1) The standardized highrise tower radically fragments the urban fabric structure and skyline, to the extent that multiple and dispersed vertical operations transform lot geometry abruptly increase building height and lower land occupation; (2) this triggers a "residentialization" effect, unbalancing existing diversity of activities and contributing to undermine urban vitality; (3) which impairs the quality of public space, by introducing exogenous typological elements (such as setbacks) and reducing contact between private space and street space.
\end{abstract}

Keywords: Santiago, Chile, residential densification process, urban morphology transformation, density parameters

\section{Introduction}

Intensive residential densification - understood as the process of building substitution that increases the number of dwellings per area unit - constitutes one of the most evident expressions of the "anchoring" of mobile capital on urban land (Weber, 2002). From the decade of the 1990s and onwards, it is possible to observe areas of increasing centrality in the Santiago Metropolitan Area (AMS) ${ }^{1}$, which are under processes of residential densification with varying degrees of intensity in the exploitation of land and forms of impact in the urban environment. This process is an expression of a real estate market that is focused exclusively on the production of affordable housing that responds to advantages of accessibility and connectivity, as well as a series of incentives for repopulation and actions taken by municipalities to attract real estate investments (López et. al., 2012).

During the last decade, in the AMS we have observed forms of hyper densification with towers that exceed 30 floors and densities that reach 10,000inhabitants/ha. Someextremecases 
have been recently called "vertical ghettos", as they generate severe negative effects on urban and residential habitability, which is due to the lack of effective policy planning and impact mitigation mechanisms. The residential highrise tower radically modifies the urban fabric through a dispersed verticalization process, based on multiple individual operations (lot by lot) that build in higher height and lower land occupation. When this process lacks gradualness, the effects and impact on urban habitability can have a significant cost. In order for the growth potential of an urban area to allow for the continuity of the transformation process, there must always be a relationship between the substitute morphological type and the substituted morphological type. This is because if the substitute type exceeds the exploitation of the land of the substituted type in an exaggerated way, there is a risk that only a few buildings will exhaust the growth potential (...), altering the fabric that was complete, but without the possibility of replacing it in its entirety (Diez, 1996).

However, residential densification is necessary, as it allows for middle and lowincome groups to have access to higher-quality locations, increasing accessibility to urban opportunities such as equipment, services and transport; it also promotes the efficiency and sustainability of urban development. It is necessary to move towards residential densification processes that contribute to enhance the quality of urban space, in favor of pedestrians and social interaction, as density is constituted as a factor of urban compactness. However, the relationship between density and urban form is highly complex.

The scarce relations between density and residential type-morphologies can lead to faults and conceptual confusions, while the form in which density materializes in the urban fabric can lead to different levels of exchanges and interactions intensity. Therefore, both authorities, urban planners and citizens need to count on objective and precise spatial references associated with density and their possibilities of materialization, which will lead to the use of normative instruments of planning and design, residential densification processes that nourish the urban space, especially in the scale of proximity and pedestrians (Campoli 2006, Pont \& Haupt 2010, Navarro \& Ortuño 2011).

This paper addresses the following question: To what extent do the processes of residential densification and the regulatory frameworks that make them possible, have an impact on the urban morphology of the Santiago Metropolitan Area (AMS)

The main objective is to contribute to objectivize the discussion regarding the impact of residential densification processes in the AMS. The hypothesis posed is that the processes of residential densification are closely related to the morphology of urban space, to the extent that densification restructures the tissue and the properties of the tissue condition the densification. They also respond to the normative and urban planning frameworks that make it possible. Consequently, the residential densification corresponds to a phenomenon that extends differently in the AMS. According to its location and moment of concretion, residential densification presents different degrees of gradualness among so many transformation processes, with different spatial manifestations and impacts on the quality of public space.

This study proposes to sophisticate density as a tool for the analysis and interpretation of the urban phenomenon, placing density in a systemic relation with other variables of the urban form, especially those that determine urban compactness and configure the public space. The systemic reading of these parameters allows the definition of typologies of residential densification, which allow the interpretation of spatial re-structuring processes of contemporary AMS.

If one understands the built environment as an agent that applies pressure on the territory and the public space as a decompressing agent of this pressure, a relationship arises between these, which spatially translates into a greater or smaller compactness of the urban fabric (BCNEcología, 2007). Therefore, the notion that density is positive is transversal, as it combines with other properties of the urban fabric and is constitutes as a factor of urban compactness, which favors pedestrians and enhances the public space as space of encounter and interaction ${ }^{2}$. 


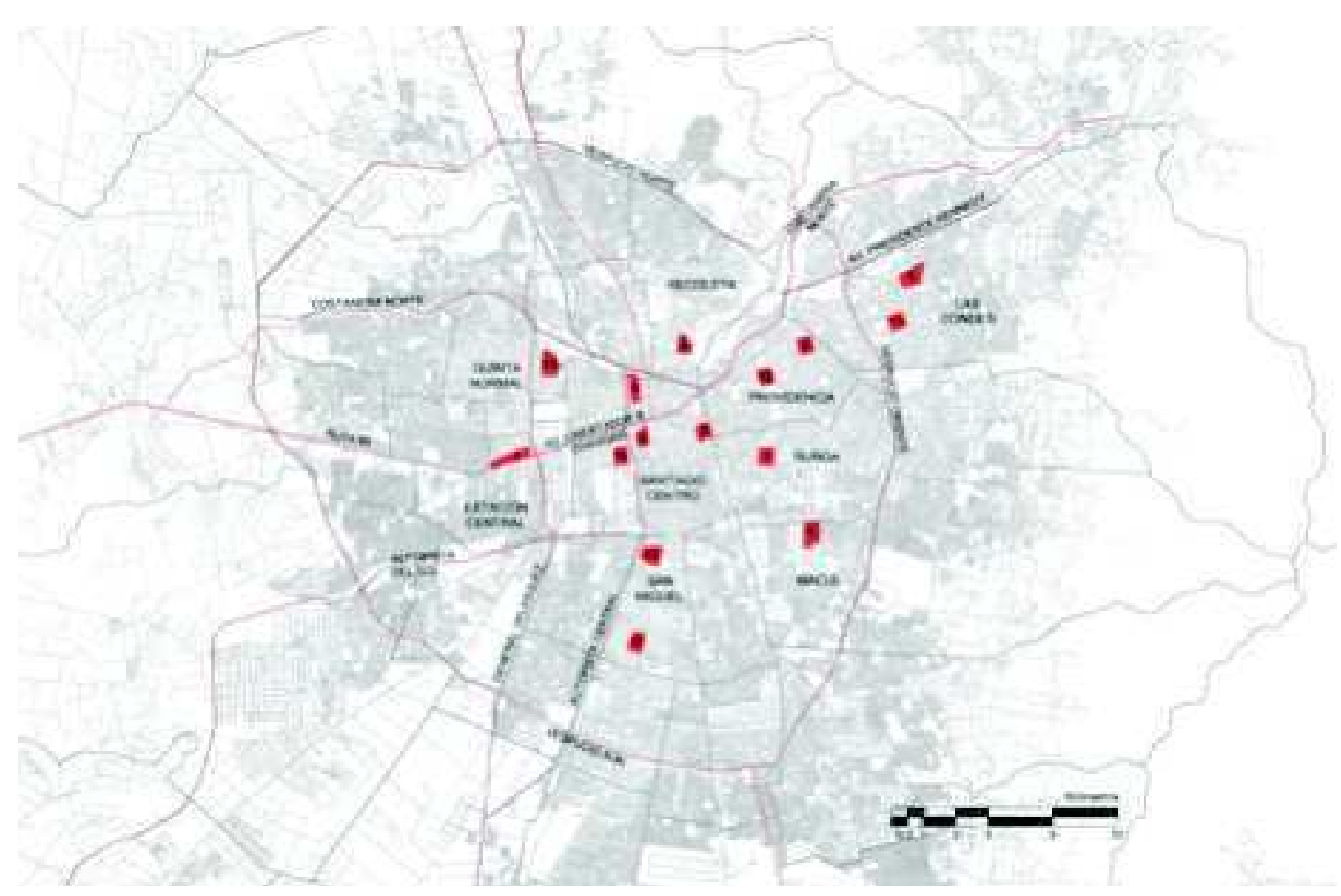

Figure 1.

Case Studies

In the last decade, a series of multivariable density models have emerged; these integrate various quantitative parameters, their relationships and effects in the urban space. We can highlight the work of Pont \& Haupt (2010), who have explored the potential of density as a planning and urban design tool, based on the analysis of the relationship between residential morphologies-types and parameters implicit in density, integrated in the Spacemate model. The work of Hoek (2008), Hausleitner (2010), Ewing et.al., Patel (2011) and Dovey \& Pafka (2014), are also noted, to name a few. These studies conclude that the density cannot be reduced to any of the variables of the urban morphology, and is better conceived as a concurrence of interconnected variables. That is, any isolated measure of density is limited and does not reflect the complexity of the urban phenomenon.

\section{Methodology}

The specific objectives of this study are the following: (1) To characterize the urban morphology of the residential densification processes in the AMS, (2) to comparatively analyze the performance parameters of the urban form to understand its impact on urban space, and (3) to define and categorize typemorphologies of residential densification, based on the configuration of these parameters in the various stages of development of the city. For this purpose, 15 fragments of approximately 25 hectares were selected, allowing for a 1: 2500 scale representation. The selection criterion consisted in obtaining a relative diversity regarding the state of densification, form and intensity of densification and relative location in the AMS. Each of these fragments constitutes a kind of "biopsy" or sample of the urban form, which allows the reading and understanding of a larger process and a larger scale.

Once selected, the morphological properties of urbanization, subdivision and edification of each fragment were represented in three dimensions (De Solá Morales, 1997). These were built based on the use of municipal property registries and photo-interpretation using Google Earth. Indicators or parameters of the urban form were constructed using the 
Table 1.

Definition of Residential Density Parameters

\begin{tabular}{|c|c|c|c|}
\hline Parameters & Calculation Formula & Scale & Description \\
\hline $\begin{array}{l}\text { Net Residential } \\
\text { Density }\end{array}$ & $\begin{array}{l}\text { Housing units / hectare (area } \\
\text { inside official limits) }\end{array}$ & $\begin{array}{l}\text { City } \\
\text { block and } \\
\text { lot }\end{array}$ & Indicates the number of housing units per area unit. \\
\hline Floor area ratio & Total built area / lot area & $\begin{array}{l}\text { City } \\
\text { block and } \\
\text { lot }\end{array}$ & $\begin{array}{l}\text { Expresses the building intensity through the relation between the } \\
\text { total built or constructed area and the total lot area. It indicates } \\
\text { the number of times the area of the city block is included in the } \\
\text { built area. It is also called edification density or edification } \\
\text { coefficient. }\end{array}$ \\
\hline $\begin{array}{l}\text { Building footprint } \\
\text { ratio }\end{array}$ & $\begin{array}{l}\text { Area built on first floor / lot } \\
\text { area }\end{array}$ & $\begin{array}{l}\text { City } \\
\text { block }\end{array}$ & $\begin{array}{l}\text { Indicates how the area of the lot at level "0" or street level is } \\
\text { occupied by the built area. }\end{array}$ \\
\hline $\begin{array}{l}\text { Residential-Use } \\
\text { Coefficient }\end{array}$ & $\begin{array}{l}\text { (Area build for residential use } \\
- \text { area built for other uses) / } \\
\text { (area built for residential use }+ \\
\text { area built for other uses) }\end{array}$ & $\begin{array}{l}\text { City } \\
\text { block }\end{array}$ & $\begin{array}{l}\text { Internalizes the ratio between residential use and other uses in } \\
\text { terms of built area. The closer to the value "1", the greater the } \\
\text { proportion of residential use compared to other uses. If the value } \\
\text { approaches "- } 1 \text { ", other uses are in greater proportion than the } \\
\text { residential uses. }\end{array}$ \\
\hline $\begin{array}{l}\text { Number of uses per } \\
\text { city-block }\end{array}$ & - & $\begin{array}{l}\text { City } \\
\text { block }\end{array}$ & Expresses the diversity of uses that are observed in a city-block. \\
\hline Open space ratio & $\begin{array}{l}\text { (1- Coefficient of land } \\
\text { occupation) } / \text { coefficient of } \\
\text { constructability }\end{array}$ & Fragment & $\begin{array}{l}\text { Expresses the impact that the different degrees and modes of } \\
\text { exploitation of land (constructability) have in the space or space } \\
\text { clearance between buildings and between the city-block and the } \\
\text { public space. The higher the coefficient of open space, the lower } \\
\text { the pressure of the building on the non-built space. }\end{array}$ \\
\hline 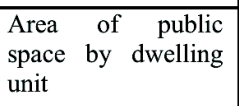 & $\begin{array}{l}\text { (Gross area }- \text { net area) } \\
\text { number of dwelling units }\end{array}$ & Fragment & $\begin{array}{l}\text { Indicates the distribution of public space area (streets, greens, } \\
\text { parks and plazas) per dwelling unit. }\end{array}$ \\
\hline $\begin{array}{l}\text { Percentage of } \\
\text { Densified Buildings }\end{array}$ & $\begin{array}{l}\left(\mathrm{N}^{\circ} \text { of lots with high rise }\right. \\
\text { towers post } 1990 / \text { Total } \mathrm{N}^{\circ} \text { of } \\
\text { lots }) * 100\end{array}$ & Fragment & $\begin{array}{l}\text { Indicates the state of progress of the densification process in the } \\
\text { fragment. }\end{array}$ \\
\hline $\begin{array}{ll}\text { Percentage } & \text { of } \\
\text { Densified Lots } & \end{array}$ & $\begin{array}{l}\text { Total area of buildings } \\
\text { corresponding to residential } \\
\text { densification post } 1990 / \text { Total } \\
\text { built area) } * 100\end{array}$ & Fragment & $\begin{array}{l}\text { Expresses how much of the total constructed area corresponds to } \\
\text { densified buildings with dwelling units. Together with the } \\
\text { percentage of densified lots and the segmentation factor, it allows } \\
\text { interpreting the degree of segmentation of the urban fabric. }\end{array}$ \\
\hline $\begin{array}{l}\text { Segmentation } \\
\text { Factor }\end{array}$ & $\begin{array}{lc}\text { Highest } & \text { constructability } \\
\text { coefficient } & / \\
\text { constructability coefficient }\end{array}$ & Fragment & $\begin{array}{l}\text { This factor expresses to what extent the constructability achieved } \\
\text { by the buildings that most intensely occupy land, move away } \\
\text { from the average constructability of the fragment. The greater the } \\
\text { factor, the greater the difference and the greater the tissue } \\
\text { segmentation. }\end{array}$ \\
\hline
\end{tabular}

bases of the census survey (INE, 2012), data from the internal revenue service (SII, 2013), and building permits and information available in real estate portals (Table 1). These were later mapped by lot and city block.

\section{Results Analysis}

From the definition and analysis of the residential density parameters (Table 2 ), along with an interpretation of the role of urban morphology as conditioner of the densification process, five typologies of residential densification are proposed for the AMS, which not only respond to the intensity of the use of land, but also to the state of progress of the residential densification and its effects on urban space. These typologies correspond to:

(1) Hyper-densification that segments the traditional urban fabric, (2) densification of the peri-central heterogeneous and diverse urban fabric, (3) densification of the homogeneous residential peri-central urban fabric, (4) Medium densification with tendency to compactness and (5) perimeter densification of the industrial macro-block.

From the analysis of these five typologies, it has been verified that, especially in the cases of hyper-densification of the traditional urban fabric, the transformation of urban space tends to produce at least three main effects: 
Table 2.

Residential Density Parameters according to densification typology in the AMS

\begin{tabular}{|c|c|c|c|c|c|c|c|c|c|c|}
\hline $\begin{array}{c}\text { Densification } \\
\text { Typology }\end{array}$ & Case & $\begin{array}{c}\text { Max. } \\
\text { Density } \\
\text { Block }\end{array}$ & $\begin{array}{c}\text { Max. } \\
\text { Density } \\
\text { Lot }\end{array}$ & $\begin{array}{l}\text { Max. } \\
\text { FAR } \\
\text { Block }\end{array}$ & $\begin{array}{c}\text { Max. } \\
\text { FAR } \\
\text { Lot }\end{array}$ & OSR & $\begin{array}{l}\text { Segm. } \\
\text { Factor }\end{array}$ & $\begin{array}{l}\text { Public Space } \\
\text { Area/ } \\
\text { Dwelling Unit }\end{array}$ & $\begin{array}{c}\% \\
\begin{array}{c}\text { Densified } \\
\text { lots }\end{array}\end{array}$ & $\begin{array}{c}\% \\
\text { Densified } \\
\text { area }\end{array}$ \\
\hline \multirow{4}{*}{$\begin{array}{c}\text { Hyper- } \\
\text { densification that } \\
\text { segments the } \\
\text { traditional urban } \\
\text { fabric }\end{array}$} & $\begin{array}{c}\text { 1. Villa } \\
\text { Israel }\end{array}$ & 436,8 & 2848,9 & 2,3 & 17,4 & 0.36 & 15,82 & 16,2 & $4 \%$ & $78 \%$ \\
\hline & $\begin{array}{c}\text { 2. Santa } \\
\text { Isabel }\end{array}$ & 362,9 & 2933 & 12 & 19,1 & 0.16 & 7,35 & 11,9 & $9 \%$ & $71 \%$ \\
\hline & $\begin{array}{c}\text { 3. Barrio } \\
\text { Bulnes }\end{array}$ & 1434,6 & 3124,2 & 8 & 16,9 & 0.11 & 4,97 & 7,6 & $13 \%$ & $69 \%$ \\
\hline & $\begin{array}{l}\text { 4. Centro } \\
\text { Histórico } \\
\end{array}$ & 1843,8 & 3019,9 & 7,0 & 25,0 & 0,09 & 7,14 & 10,4 & $16 \%$ & $34 \%$ \\
\hline \multirow{3}{*}{$\begin{array}{c}\text { Densification of } \\
\text { the peri-central } \\
\text { heterogeneous and } \\
\text { diverse urban } \\
\text { fabric }\end{array}$} & $\begin{array}{c}\text { 5. Barrio } \\
\text { Punta de } \\
\text { Rieles } \\
\end{array}$ & 265 & 913,13 & 0,8 & 6,8 & 0.63 & 11,33 & 23,3 & $5 \%$ & $71 \%$ \\
\hline & $\begin{array}{l}\text { 6. Barrio } \\
\text { Patronato }\end{array}$ & 527 & $\begin{array}{c}1556,0 \\
2\end{array}$ & 2,44 & 7,8 & 0.49 & 7,65 & 51,6 & $8 \%$ & $57 \%$ \\
\hline & $\begin{array}{c}\text { 7. Barrio } \\
\text { Eusebio } \\
\text { Lillo }\end{array}$ & 270 & 1516,9 & 2,4 & 14 & 0.53 & 12,73 & 19,0 & $13 \%$ & $76 \%$ \\
\hline \multirow{2}{*}{$\begin{array}{l}\text { Densification of } \\
\text { the homogeneous } \\
\text { residential peri- } \\
\text { central urban } \\
\text { fabric / advanced } \\
\text { densification }\end{array}$} & $\begin{array}{l}\text { 8. Barrio } \\
\text { Las Lilas } \\
\end{array}$ & 217,8 & 616,7 & 2 & 5,6 & 0.47 & 4,31 & 21,0 & $24 \%$ & $45 \%$ \\
\hline & $\begin{array}{c}\text { 9. Barrio } \\
\text { Escandinavi } \\
\text { a }\end{array}$ & 499,1 & 877,6 & 3,2 & 5,3 & 0,38 & 2,79 & 24,1 & $52 \%$ & $96 \%$ \\
\hline \multirow{3}{*}{$\begin{array}{l}\text { Densification of } \\
\text { the homogeneous } \\
\text { residential peri- } \\
\text { central urban } \\
\text { fabric/ } \\
\text { incomplete } \\
\text { densification }\end{array}$} & $\begin{array}{c}\text { 10. Barrio } \\
\text { Llano } \\
\text { Subercasea } \\
\text { ux } \\
\end{array}$ & 114 & 960,7 & 2,5 & 11,8 & 0,61 & 9,83 & 24,6 & $15 \%$ & $89 \%$ \\
\hline & $\begin{array}{l}\text { 11. Barrio } \\
\text { Los } \\
\text { Descubrido } \\
\text { res }\end{array}$ & 398,2 & 541,5 & 4 & 5 & 0.36 & 2,78 & 15,0 & $21 \%$ & $79 \%$ \\
\hline & $\begin{array}{l}\text { 12. Barrio } \\
\text { Los } \\
\text { Estanques }\end{array}$ & 238,1 & 1020,1 & 2 & 5,4 & 0.49 & 4,15 & 36,2 & $37 \%$ & $79 \%$ \\
\hline $\begin{array}{l}\text { Densification of } \\
\text { the homogeneous } \\
\text { residential peri- } \\
\text { central urban } \\
\text { fabric / intensive } \\
\text { and incipient } \\
\text { densification }\end{array}$ & $\begin{array}{l}\text { 13. Barrio } \\
\text { Atacama }\end{array}$ & 153,8 & 1367 & 1,2 & 7,5 & 0.89 & 10,71 & 24,6 & $6 \%$ & $69 \%$ \\
\hline $\begin{array}{c}\text { Medium } \\
\text { densification with } \\
\text { tendency to } \\
\text { compactness }\end{array}$ & $\begin{array}{l}\text { 14. Barrio } \\
\text { República }\end{array}$ & 269,4 & 3022,9 & 1,9 & 6,6 & 0,31 & 5,08 & 20,2 & $8 \%$ & $48 \%$ \\
\hline $\begin{array}{l}\text { Perimeter } \\
\text { densification of } \\
\text { the industrial } \\
\text { macro-block }\end{array}$ & $\begin{array}{l}\text { 15. Barrio } \\
\text { Estación } \\
\text { Yungay }\end{array}$ & 598,3 & 848,6 & 3,2 & 6,8 & 0,27 & 3,58 & 15,8 & $42 \%$ & $65 \%$ \\
\hline \multicolumn{2}{|c|}{ Sample Average } & 508,6 & 1677,8 & 3,7 & 10,7 & 0,4 & 7,3 & 21,4 & $18 \%$ & $68 \%$ \\
\hline
\end{tabular}

Firstly, as the substituting model does not adapt to the substituted urban fabric - in the absence of a minimal degree of gradualness of the substitution - the standardized highrise tower produces effects on the image and skyline, as well as on existing urban and architectural heritage. Habitability is degraded by the high pressure on the open space, not only towards the inside of the block, but also towards the street space, which is manifested not only in terms of greater demands of the public equipment, transport and the public space, but also in terms of environmental conditions such as sun-light exposure, ventilation, noise, privacy and access to views, among others.

Secondly, intensive residential densification 


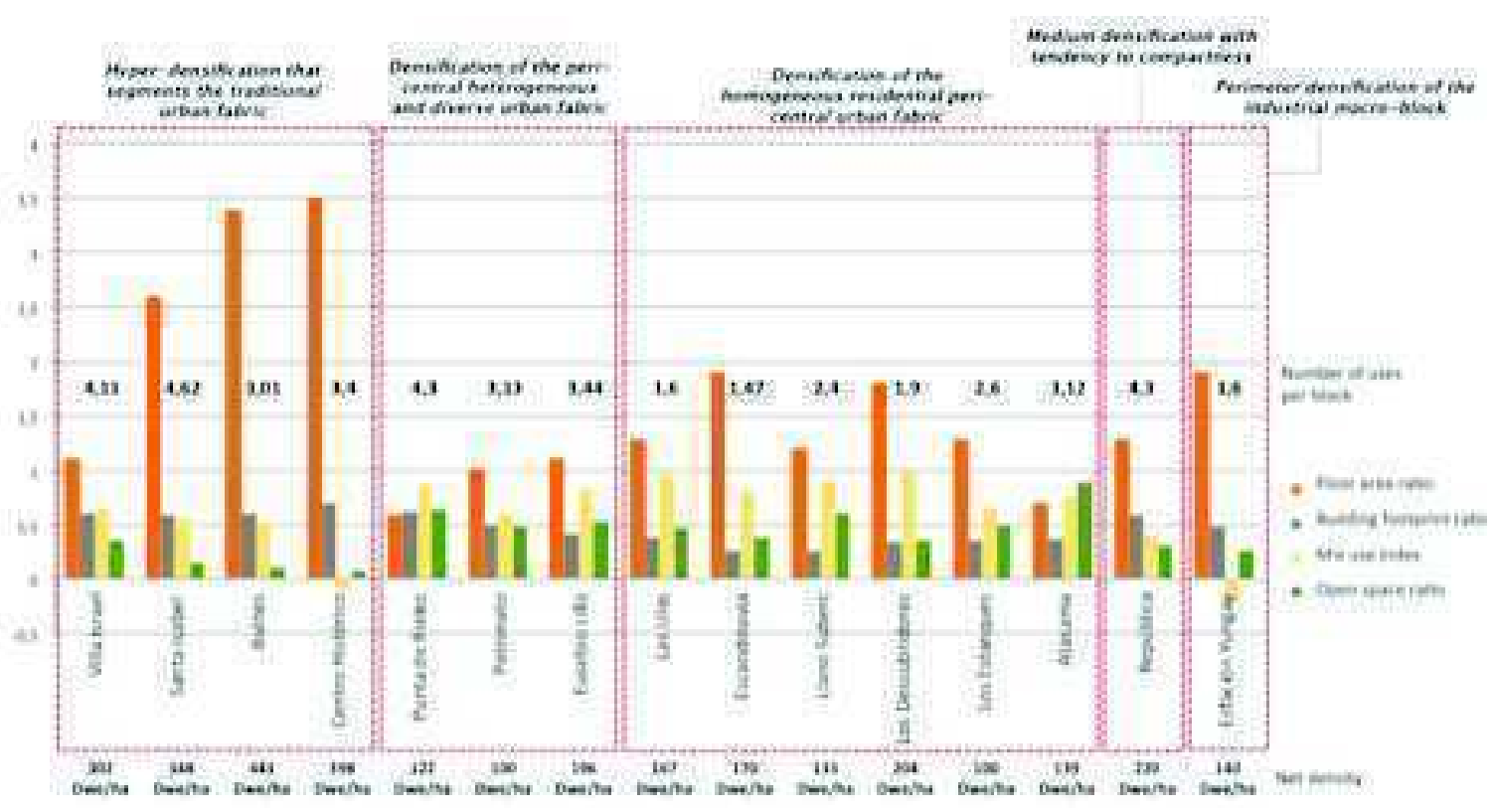

Figure 2.

Typologies of densification in the AMS and parameters of the urban form

triggers a "residentialization" effect, unbalancing the diversity of uses and on occasions reducing urban complexity and vitality in areas of high centrality. As private high-rise condominiums become increasingly self-sufficient, incorporating a series of equipment for exclusive use of land lords, the urban context increasingly has less to offer in terms of complementary uses to residential housing.

Thirdly, intensive densification can damage the quality of public space, as it implies its fragmentation, especially in streets with plans for road widening, when exogenous typological elements are introduced (such as front yards and the isolated tower in neighborhoods of continuous façades) or when the residentialization or lot-fusion reduces space for transition between the private space and the street space. The interface between the public and private domains is especially critical in these processes, as higher densities should be accompanied by larger areas of public space and higher standards of urban design, equipment and services.

Below we will discuss these effects from the analysis of the parameters of the urban form. We will focus on the typology of hyperdensification that segments the traditional urban fabric, since it is the one that generates the greatest impact on the urban space.

Hyper-densification in the AMS produces significant effects on the morphology of the urban fabric: The residential high-rise tower fragments the existing fabric and radically modifies the existing building structure, from a dispersed verticalization process. This is mainly observed in very central areas or areas with increasing degrees of centrality, where the traditional urban fabric predominates, with a continuous façade of one or two stories (or heights of up to 10 stories, where previous densification processes are observed) and where the dwelling use coexists with services, commerce and various equipment. A very liberal normative makes this typology possible; restrictions on height, density or floor area ratio have been largely absent.

The residential densification operation consists of the fusion of two or three lots to raise one or two towers of up to 30 or 40 stories (mainly in a "T" or "L" shaped plan to take advantage of the building geometry); this creates a disruption in the existing urban fabric. The densities exceed 1,800 dwelling units / ha per block and 3,000 dwelling units / ha in some cases. Floor area ratio levels of the building are also extremely high (12 per block and 25 per block).

City blocks have larger dimensions, 


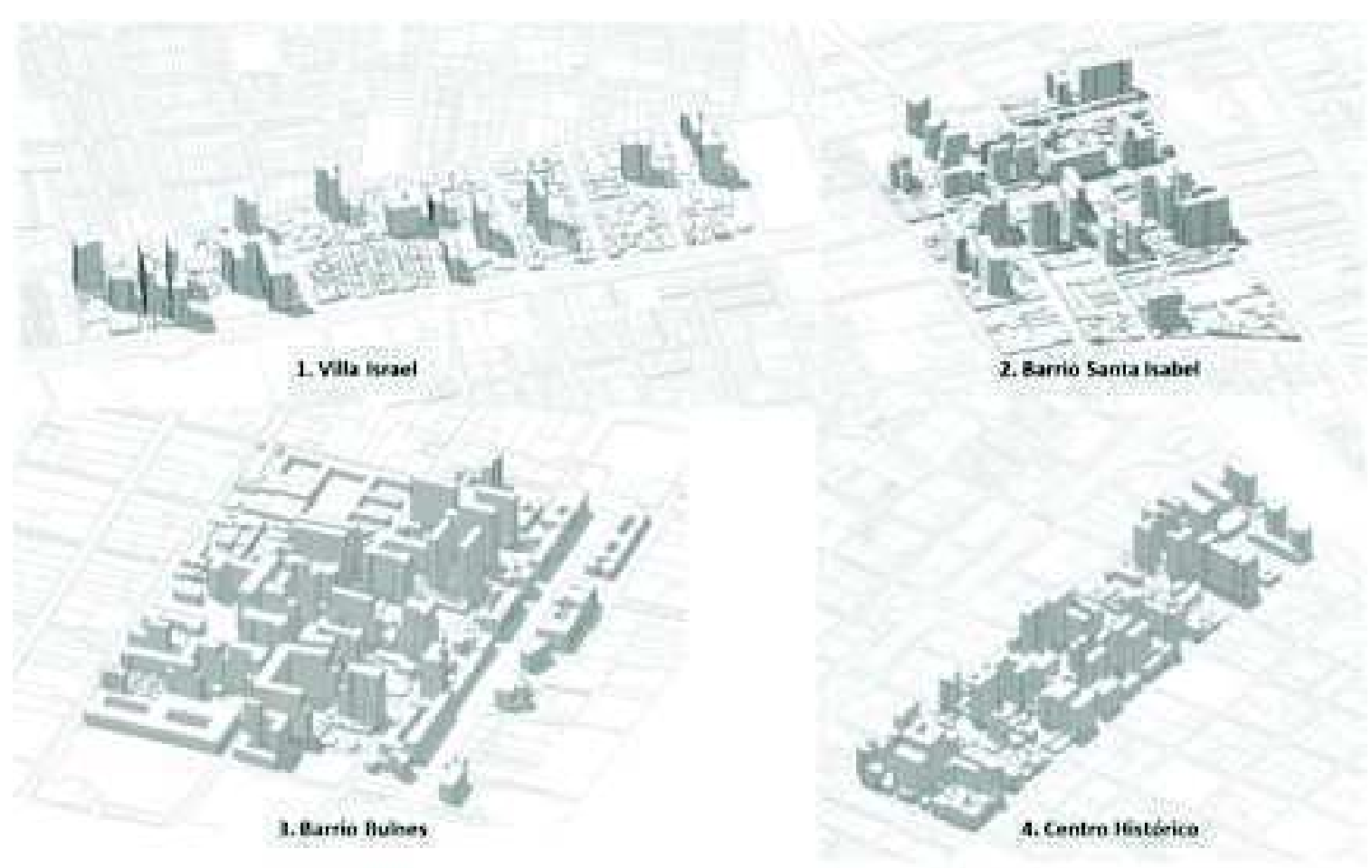

Figure 3.

Hyper-densification that segments the traditional urban fabric

resulting in a smaller surface area of streets and sidewalks. Since the process of hyperdensification does not go along with openings or widening of new streets and implementation of new green areas and public spaces, we can also observe low public space area per dwelling unit.

The high levels of intensity of land occupancy impact on the space or space clearance between buildings and between the city block and the public space. Alike the area of public space per dwelling unit, the coefficients of open space correspond to the lowest of the sample, which has significant implications in terms of sunlight exposure, ventilation and availability of open views from dwellings units. For example, the coefficient of open space in the Historic Center is 10 times lower than in the Barrio Atacama (San Miguel).

Inthistypology, wecanobservetwocategories that differ by the degree of segmentation of the urban fabric. On the one hand, the case of Villa Israel has the highest segmentation factor of the sample (16). This is due to the incipient degree of progress of the densification process, which, given the significant floor area ratios and maximum heights reached, imply a greater degree of disruption of the substituent tissue over the substituted one. In fact, only $4 \%$ of the properties of the fragment contribute to $78 \%$ of the total built area. On the other hand, the cases of Santa Isabel, Centro Histórico and Barrio Bulnes present a more consolidated stage of densification, where residential towers coexist with some office towers or equipment in height, which reduces the degree of segmentation of the fabric, but increases the pressure of the space built over the open space.

In terms of Diez, the process of residential densification produces a segmentation of the urban fabric, insofar as the exploitation of the land is low if it is calculated in function of the building with highest level of exploitation. We can observe that a few buildings would be depleting the growth potential of the urban fabric, altering it without the possibility of replacing its entirety and triggering a segmentation that becomes irreversible. In fact, if the floor area ratio is measured in the scale of the lot, the dispersion of this indicator within the block is significant, coexisting constructions with floor area ratios of 0.5 with 


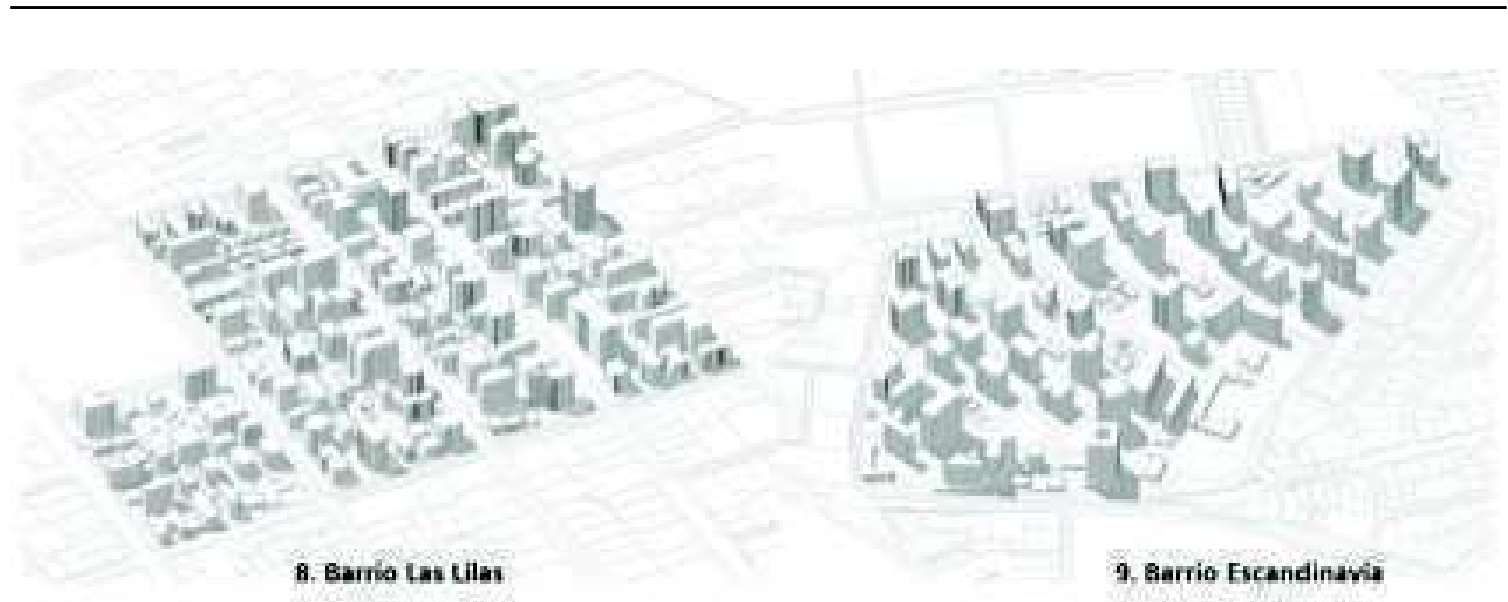

Figure 4.

Densification of the homogeneous residential peri-central urban fabric / Advanced densification.

high-rises that reach a floor area ratio of 20 . Something similar occurs with the indicators of land occupation: While older buildings occupy more than 60 or $70 \%$ of the land, mainly under the principle of aggregation of continuous facade, the occupancy in the first story of the residential tower fluctuates between 20 and $40 \%$.

On the contrary, regarding the typology of Densification of the homogeneous residential peri-central urban fabric (Figure 4), the coherence of the urban space observed after the process of residential densification, is the product of an urban regulation that has established height limits and floor area ratio that are consistent with minimum building subdivision parameters that promote a relatively homogenous densification typology.

Land occupancy coefficients are low and tend to be similar in the high-rise typology and in those of one and two stories (between 0.3 and 0.4 , approximately), which determines that the coefficients of open space are around the average of the sample. Also, the regulations have established landscaping and urban design standards that 'protect' the character of garden city with which these neighborhoods were born. It should also be noted that its relative location in the AMS (high income cone with high degrees of centrality) and the quality of the urban design of its public spaces determine that the high demand for living in these neighborhoods has triggered "sufficient constructive energy" o renew much of the urban fabric.
Consequently, they conform the cases with high coefficients of residential use and the lower diversity of uses per city block of the sample. With parameters of gross and net density of 125 and 170 units / ha, the process of densification of the edificatory fabric approaches a state conformed by only two building types (the residential tower and the single family dwelling) with the same principle of aggregation and exploitation of the soil (isolated building with front yard). There is coherence between the pre-existing parceling and the increase of the property surface in order to increase height and density. Both the pre-existing lot fabric structure as well as the processes of lot fusion is relatively homogeneous, so that a same floor area ratio coefficient translates into relatively similar overall constructed areas. The coherence of the urban space is the product of a coordinated action between the public and private agents.

In the typology of hyper-densification we can find a great variety of uses per block, (some of which can reach up to seven uses). However, despite the diversity of uses, it is also possible to observe a slight predominance of residential use (with the exception of the Historic Center). This process of residentialization can be critical and paradoxical, as the new residents do not have the necessary equipment, and despite their excellent conditions of access to public transport, they must commute to other sectors of the city for daily activities. 
Hyper-intensity of densification is possible to achieve precisely because a standardized model of residential high-rise tower has been implanted and proven to be a product of fast execution and high profitability. This mismatch is more pronounced as we observe the parameters in the lot scale, where we find densities of 3000 units / ha living in a city bock with densities of 10 units / ha. The typological diversity of the substituted city block, especially in terms of the parceling, is determinant of the segmentation of the constructed tissue. The lot structure of the existing fabric constitutes the result of multiple fusions and lot subdivisions taken place for more than 150 years, therefore in the segmented tissue the lot of highest buildability can be 30 times denser in volume than the lot of the lowest buildability.

In effect, where the isolated residential tower "irrupts", there is an "emptying" of the city block at ground level, especially in areas where the predominant building structure tends to be of continuous grouping at low height. The dispersed renovation produces transformations at street level, mainly in two directions: (1) To reach higher heights the towers are located in the center of the lot, keeping distance from the street and bringing a new morphological element to the neighborhood: The front yard, and (2) the process of building fusion implies the reduction of accesses and spaces of contact between the private space and the street space.

\section{Conclusion}

The typologies of intensive residential densification proposed in this study permit an objective discussion regarding one of the main contemporary phenomena of spatial re-structuring. Also, they allow a deeper understanding of this process, by differentiating their particular spatial characteristics, their degrees of intensity of use of land at different scales (lot, city block and fragment) and progress of this process of urban transformation.

These parameters of the urban form have contributed to firstly measure the intensity of this process, not only in terms of the final densities (dwelling units / hectare), but also of other urban space variables that are altered through the process of intensive densification (grouping principles, alignment and forms of relationship between the private space and the public space, as well as degrees of edification, occupation of land, use mixture and open space). Second, to measure the extent to which these processes fragment the urban space, with irreversible impacts on urban habitability.

The morphological characteristics of urban space, specially the particularities of urbanization and subdivision, are elements that condition the forms of intensive densification. In the absence of normative constraints in territorial planning instruments, the geometry and use of pre-existing blocks and lots, such as lot dimensions, typological diversity of lots, obsolete industrial uses or availability of large lots, just to name a few, are conditioning factors of spatiality resulting from densification.

Not all forms of densification contribute to build a more vital and compact city. It is precisely the components of urban space that should consist of the basis of the design of regulations that direct or lead a more friendly densification process, with better standards of urban habitability. For example, in those sectors with a high geometric diversity of the urban fabric, the conditioners of edification based on coefficients that are applied to the characteristics of the lot do not assure a morphological coherence in the process of densification.

Residential densification can contribute to an improvement in urban quality, insofar as normative planning considers the relationship between the spatial properties of the substituted tissue and the substituting tissue, balancing parameters that constitute factors of urban compactness. This requires the incorporation of more sophisticated normative mechanisms to those currently used today, which exceed the lot as an operational element of planning, based on morphological parameters that enrich the prefiguration of public space according to the proposed city project. These constitute social agreements that imply a model of city and an idea of urbanity. Therein lies the importance of having planning and urban design instruments that guarantee densification processes that contribute to a greater urban quality. 


\section{Notes}

1 The Metropolitan Area of Santiago (AMS) is understood to mean the 34 communes that make up the nucleus of the urban system (communes of Santiago Province plus San Bernardo and Puente Alto) (De Mattos, Fuentes \& Link, 2014).

2 Jacobs 1961, Lynch 1962, 1980, Rapoport 1975, Hoek 2008, Ewing \& Cervero 2010, Pont \& Haupt 2010, Hausleitner 2011, among others.

\section{References}

$\mathrm{BCN}$, Agencia de Ecologia Urbana de Barcelona. Plan de movilidad y espacio público Vitoria-Gasteiz, España. 2007.

Boyko, Christopher T.; COOPER, Rachel. Clarifying and re-conceptualising density. Progress in Planning, 2011, vol. 76, no 1, p. $1-61$.

Ryan, Brent D.; Weber, Rachel. Valuing new development in distressed urban neighborhoods: Does design matter? Journal of the American Planning Association, 2007, vol. 73, no 1, p. 100-111.

Campoli, Julie \& Maclean, Alex. Visualizing Density. Cambridge, Mass.: Lincoln Institute of Land Policy, 2006.

Churchman, Arza. Disentangling the concept of density. Journal of Planning Literature, 1999, vol. 13, no 4, p. 389-411.

De Mattos, Carlos; Fuentes, Luis; Link, Felipe. Tendencias recientes del crecimiento metropolitano en Santiago de Chile:¿ Hacia una nueva geografía urbana?. Revista invi, 2014, vol. 29, no 81, p. 193-219.

De Solá Morales i Rubió, Manuel. Las formas de crecimiento urbano. Barcelona: Eds. UPC. 1997.

Diez, Fernando. Buenos Aires y algunas constantes en las transformaciones urbanas. Buenos Aires: Fundación Editorial Belgrano. 1996. p.96

Dovey, Kim; Pafka, Elek. The urban density assemblage: Modelling multiple measures. Urban Design International, 2014, vol. 19, no 1 , p. 66-76.
Ewing, Reid; Cervero, Robert. Travel and the built environment: a meta-analysis. Journal of the American planning association, 2010, vol. 76, no 3, p. 265-294.

Gehl, Jan. Cities for People. Washington: Island Press. 2010.

Hausleitner, B. Tracing Scopes of Action: Design Principles to Approach the Complexity of the Urban Block: Along Case Studies in [Paris]. 2010.

Van den Hoek, Joost. The MXI (Mixed-use Index) an Instrument for Antisprawl Policy. En 44th ISOCARP Congress, Dalian, China. 2008.

Jacobs, Jane. The death and life of great American cities. New York: Modern Library. 1961.

Martin, Leslie; March, Lionel. Urban space and structures. Cambridge University Press, 1972.

Navarro Vera, José Ramón; Ortuño Padilla, Armando. Aproximación a la génesis de la contribución de la densidad en la noción de" ciudad compacta".EURE (Santiago), 2011, vol. 37, no 112, p. 23-41.

Newman, Peter; Kenworthy, Jeffrey. Sustainability and cities: overcoming automobile dependence. Island press, 1999.

Patel, Shirish B. Analyzing urban layouts-can high density be achieved with good living conditions?. Environment and Urbanization, 2011, vol. 23, no 2, p. 583-595.

Berghauser-Pont, M. Y.; Haupt, Per. Spacematrix: space, density and urban form. Rotterdam: NAi Publishers, 2010.

Rapoport, Amos. Toward a redefinition of density. Environment and Behavior, 1975, vol. 7, no 2, p. 133-158.

Vicuña, M. (2015). Las Formas de la Densidad Residencial. El Caso del Gran Santiago. Directora de Tesis: Rosanna Forray. Tesis Doctorado en Arquitectura y Estudios Urbanos, Pontificia Universidad Católica de Chile

Weber, Rachel. Extracting value from the city: neoliberalism and urban redevelopment. Antipode, 2002, vol. 34, no 3, p. 519-540. 